\title{
OPTIMALIZÁLT NANOPLAZMONIKA
}

\author{
Balázs Bánhelyi ${ }^{1}$, Fekete Olivér ${ }^{2}$, Sipos Áron $^{3}$, \\ Szenes András ${ }^{2}$, Tóth Emese ${ }^{2}$, Vass Dávid², Csete Mária ${ }^{2}$
}

${ }^{1}$ Szegedi Tudományegyetem, Számitógépes Optimalizálás Tanszék, Árpád tér 2, 6720 Szeged;

${ }^{2}$ Szegedi Tudományegyetem, Optikai és Kvantumelektronikai Tanszék, Dóm tér 9, 6720 Szeged;

${ }^{3}$ Szegedi Biológiai Kutatóközpont, Biofizika Intézet, Temesvári krt. 62, 6720 Szeged; Magyarország.

DOI: https://doi.org/10.14232/kvantumelektronika.9.3

\section{Bevezetés}

A fény-anyag kölcsönhatás jelenségei optimalizálhatók a plazmonikus spektrumszerkesztés elveinek megfelelően tervezett nanorezonátorok alkalmazásával. Az individuális nanorezonátorok kivilágítási konfigurációjának valamint a periodikus és komplex struktúrák diszperziós karakterisztikájának tervezéséhez új numerikus eljárást dolgoztunk ki. Az optimális paraméterek biztosításához megfogalmazott célfüggvények és kritériumok alkalmazása lehetővé tette egyfoton detektorok abszorpciójának maximalizálását a polarizáció szelektivitás maximalizálásával és minimalizálásával; egyfoton források spontán emissziójának erősítését és szupersugárzás elérését; individuális, periodikus és komplex struktúrák tervezését, amelyekkel a fluoreszcens festékek fénykibocsátása a gerjesztés és az emisszió együttes erősítésével maximalizálható. A módszer lehetővé teszi hatékony egyfoton források és detektorok létrehozását a kvantuminformatikai alkalmazások céljaira, valamint plazmonikus bio-platformokon a szenzorizációs specifikusság és érzékenység javítását.

\section{Plamonikus struktúrával integrált egyfoton detektorok}

A szupravezető nanohuzalokon alapuló egyfotondetektorok (superconducting nanowire single photon detectors: SNSPD) optimalizálását először az abszorpció (A-SNSPD) valamint a polarizációkontraszt maximalizálására valósítottuk meg, utóbbit a párhuzamosan teljesítendő abszorpcióra vonatkozó kritériummal (C-SNSPD) és anélkül (P-SNSPD). Az A-SNSPD-vel elérhető legnagyobb abszorpció 95\%, a C-SNSPD esetében korrelációkat mutattunk ki a konfigurációs paraméterek között, a P-SNSPD-vel elérhető legnagyobb polarizáció kontraszt $10^{13}$ nagyságrendü volt [1-2].

Az SNSPD hatásfokot polarizáció-függetlenül törésmutató kontrasztot kompenzáló anyagokkal, spirális huzalokkal, és keresztezett nanohuzal mintázatokkal növelték meg korábban. A plazmonikus erősítés polarizáció specifikusságának figyelembe vételével két egymásra merőleges és vertikálisan eltolt nióbium-nitrid $(\mathrm{NbN})$ mintázatot kétdimenziós plazmonikus rácsokkal integráltunk.

(a)

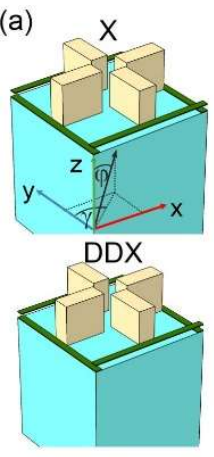

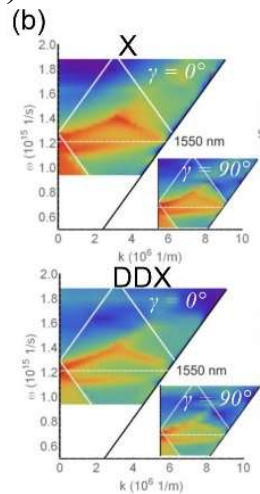

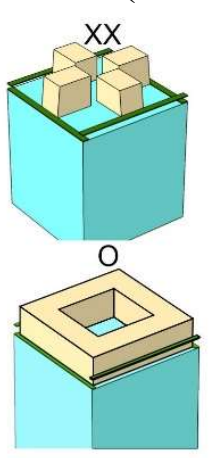

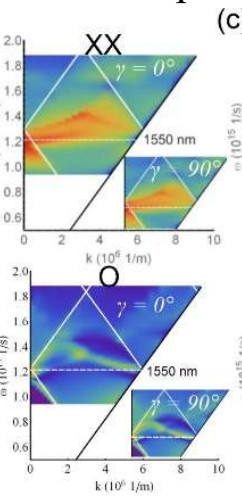

1. ábra (c)

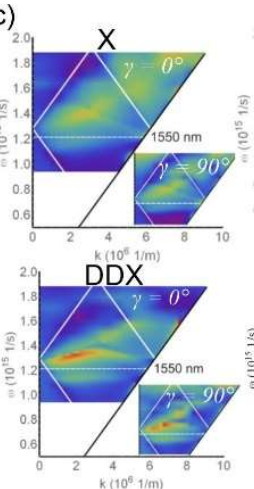

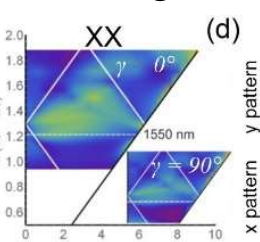

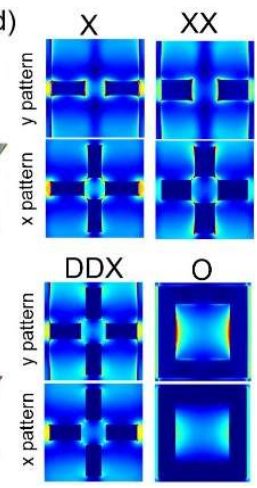

Polarizációtól függetlenül nagy abszorpció biztosítására tervezett (a) NCTAI-X \& XX, NCDDAI-X \& NCTDAI-O típusú detektorok, az optimalizált rendszerek diszperziós karakterisztikája (b) p-polarizált abszorpcióban és (c) polarizáció kontrasztban,

(d) a közeltér eloszlása az abszorpció maximumoknál. 
A (nanocavity-trench-array-integrated) NCTAI-X/XX-SNSPD-ben a periodikus mintázatok a szubsztrát síkja felett helyezkednek el, míg a nanoüreg vertikális falai merőlegesek/szöget zárnak be a határfelülethez képest. A (nanocavity-double-deflector-array-integrated) NCDDAI-X / (nanocavity-trench-deflector-array-integrated) NCTDAI-O-SNSPD-ben a vertikális szegmensek a szubsztrátba mélyülnek mindkét / az egyik aranyrácsban, továbbá a geometria paramétereket az x és az y tengely mentén csak vertikális / minden irányban egymástól függetlenül variáltuk (1(a) ábra).

A diszperziós karakterisztika feltételes optimalizálása lehetővé tette azon integrált detektor paraméterek meghatározását, amelyekkel nagy abszorpció $(\mathrm{A}>0.9)$ és egységhez közeli polarizáció kontraszt (PC 1) érhető el közel merőleges beesésben egy plazmonikus áteresztő sávon belől, a ppolarizáció esetében az MIM módusokkal csatolással erősítve (1(b) és 1(c) ábrák).

A vertikális falú NCTAI-X köztes abszorptanciát mutat a legnagyobb sávszélesség mellett (2(a) ábra). A döntött falú NCTAI-XX mutatja a legkisebb poláris szögben integrált PC-t azonban ezt köztes abszorpció, köztes hullámhosszban és legnagyobb azimutális szögben integrált PC kíséri (2(b) és 2(c) ábrák). Az NCDDAI-X teszi lehetővé a legnagyobb abszorpció elérését zérus elhangolással és közel egységnyi PC értéket merőleges beesésnél a legszélesebb spektrális tartományban, továbbá köztes azimutális szögben, de legkisebb hullámhosszban integrált PC értéket. Hátrányai a döntésre való érzékenység, és a kis sávszélesség az abszorpcióban.

Újabb vizsgálataink szerint az NCTDAI-O abban az esetben tud kompetitív lenni, amikor az MIM üregek hosszát kompenzáljuk, amely lehetővé teszi az egységhez közeli abszorpció elérését. Az NCTDAI-O mutatja a legkisebb átlagos NbN abszorpciót és sávszélességet, a legnagyobb poláris szögben és hullámhosszban integrált PC értéket, azonban a legalacsonyabb azimutális szögben integrált PC devianciájának és szegmens specifikus érzékenységének köszönhetően specifikus alkalmazások céljaira megfelelő választásnak bizonyulhat.

(a)
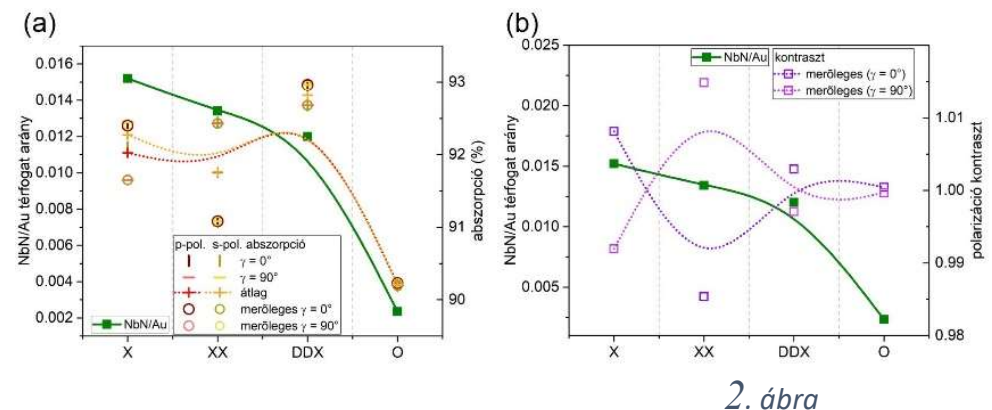

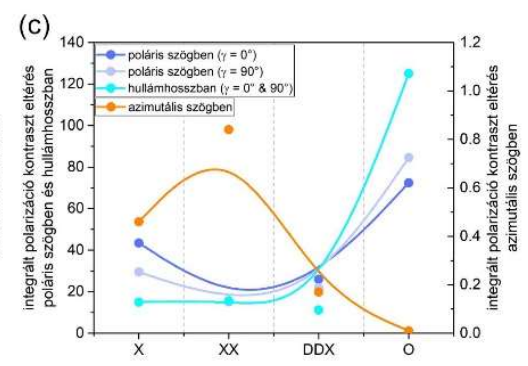

A vizsgált SNSPD rendszerekben az NbN/Au korrelációja az (a) NbN abszorpció és (b) polarizáció kontraszt értékekkel; (c) az integrált polarizációkontraszt értékek.

\section{Plazmonikus nanorezonátorokkal erösített egyfoton források}

A gyémántba implementálható nitrogén (NV) és szilícium (SiV) színcentrumok emissziójának erősítésére különböző individuális és dimer plazmonikus nanorezonátorokat terveztünk. A gerjesztés és emisszió hullámhosszán megadott teljes sugárzási ráta erősítések ( $\mathrm{P}_{\mathrm{x}}$ faktor) és az emisszión megadott korrigált kvantumhatásfok (cQE) szorzatának maximalizálása vezetett a leghatékonyabb konfigurációkra. Gyémánttal bevont ezüst és arany individuális és dimer nanorudakat, valamint ezüst és arany héjba zárt gyémánt magot tartalmazó nanorezonátor konfigurációkat optimalizáltunk a színcentrumok emissziójának erősítésére. Az ezüst nanorezonátorokkal a gerjesztés is erősíthető, ugyanakkor mindkét fém alkalmas az emisszió erősítésére. Az emisszió erősítése mellett az SiV színcentrum intrinsic kvantumhatásfokánál jobb hatékonyságot mutató csatolt emitter-nanorezonátor rendszerek is tervezhetők specifikus kvantuminformatikai célokra [3, 4]. 
Szuperradiancia akkor következik be, amikor N emitter kooperativitásának eredményeként a sugárzási ráta $\mathrm{N}$-szeresére növekedik, így az emisszió $\mathrm{N}^{2}$-el lesz arányos. Plazmonikus Dicke effektus szilárd fém nanorészecskék körül elrendezett, és mag-héj nanorezonátorokba helyezett emitterek esetében is előidézhető. A konvex mag-héj nanorezonátorokban a több mediáló plazmonikus módus létezése miatt az irodalom szerint elérhető ráta N/3-al arányos. A konkáv nanorezonátoroknál a sugárzás távoltérbe jutását is biztosítani szükséges.

Az SiV színcentrumok ideális jelöltek kooperatív fluoreszcencia (szupersugárzás) demonstrálására is a gerjesztésen és emisszión egymásra merőleges dipólusmomentumuknak köszönhetően. Gyémántezüst (csupasz) és gyémánt-ezüst-gyémánt (bevont) nanorezonátorokat optimalizáltunk, amelyekben 4 vagy $6 \mathrm{SiV}$ színcentrumot helyeztünk el szimmetrikus és aszimmetrikus rektanguláris és hexagonális mintázatban (csupasz/bevont_SiV darabszám formátumban hivatkozva).

A szférikus és ellipszoidális geometria összehasonlítása során az állításokat az ellipszoidális geometriára fogalmaztuk meg. A csupasz/bevont ellipszoidális nanorezonátorok kisebb/nagyobb kvantumhatásfokot és nagyobb Purcell faktor tesznek lehetővé a két/egy nagyságrenddel nagyobb felhalmozott töltésennyiségnek megfelelően, így nagyobb gerjesztési ráta növekedést eredményeznek (kivéve az aszimmetrikus mintázat a bevont_6 nanorezonátorokban). A nagyobb kvantumhatásfok, kétszer/egy nagyságrenddel kisebb töltéssel korreláló kisebb Purcell faktor kisebb emisszió erősítést és távoltérbe kisugárzást tesz lehetővé (3. ábra).

A spektrális válaszok félértékszélessége nagyobb, ennek megfelelöen a $\mathrm{Q}$ faktor több mint kétszer kisebb, ami jobban definiált bad-cavity karakterisztikát bizonyít. Az ellipszoidális nanorezonátorok nagyobb frekvenciahúzást mutatnak a kisebb Q faktornak köszönhetően, ami korrelál a jobb szuperradiancia jósággal. A szuperradiancia minden nanorezonátorral széles tartományban elérhető (4(a) ábra). A lasing jelenség szempontjából fontos vonalszélesség csökkenés is megfigyelhető minden szimmetrikus mintázat esetében (kivéve a bevont_4 ellipszoidális nanorezonátort). Aszimmetrikus mintázatokra vonalszélesség csökkenés a csupasz (szférikus) ellipszoidális nanorezonátorokban (sugárzási ráta növekményben) Purcell faktorban figyelhető meg, míg a bevont nanorezonátorok közül csak az ellipsziodálisok esetében, de ott mindkét mennyiségben bekövetkezik.
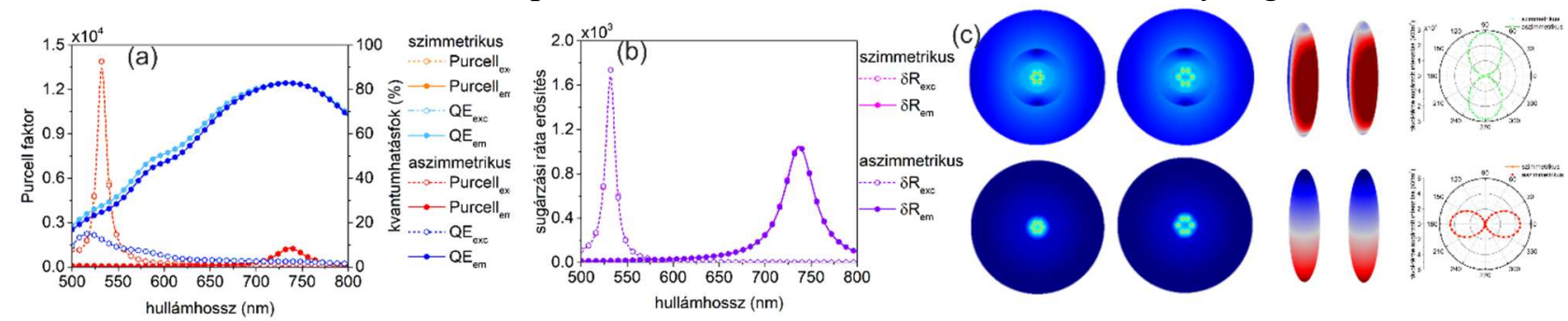

3. ábra

A legjobb szuperradiancia karakterisztikát mutató 6 SiV színcentrumot szimmetrikus és nem-szimmetrikus elrendezésben tartalmazó csupasz nanorezonátorok (a) kvantumhatásfoka és Purcell faktora, (b) sugárzási ráta erősitése,

(c) a létrejövő töltés, közeltér és távoltér eloszlás.

Kimutattuk, hogy a szimmetrikus és nem-szimmetrikus mintázatban elhelyezett 4 SiV színcentrum megkülönböztethetetlen. Ezzel ellentétben a $6 \mathrm{SiV}$ színcentrum a gerjesztésen két megkülönböztethető, 2- és 4-szeres degenerációt mutató ágra hasad, amelyek a csupasz / bevont esetekben eltérő / hasonló Purcell faktor tendenciát mutatnak a szférikus és ellipszoidális nanorezonátorokban (4(b) és 4(c) ábrák). Ennek oka a mező távolságfüggő átpolarizálása (4(d) ábra). A szuperradiancia jellemzésére választott 6 mennyiség $\left(\mathrm{P}_{\mathrm{x}}, \mathrm{P}_{\mathrm{x}} \mathrm{cQE}, \mathrm{Q}, \Sigma \delta \mathrm{X}, \Delta \lambda, \Delta \mathrm{f}\right)$ mindegyike jobb az ellipszoidális nanorezonátorokban, kivéve az elhangolás néhány optimalizált esetben. Mindezek alapján az ellipszoidális nanorezonátorok javasolhatók szupersugárzás elérésére (4(e) ábra). 

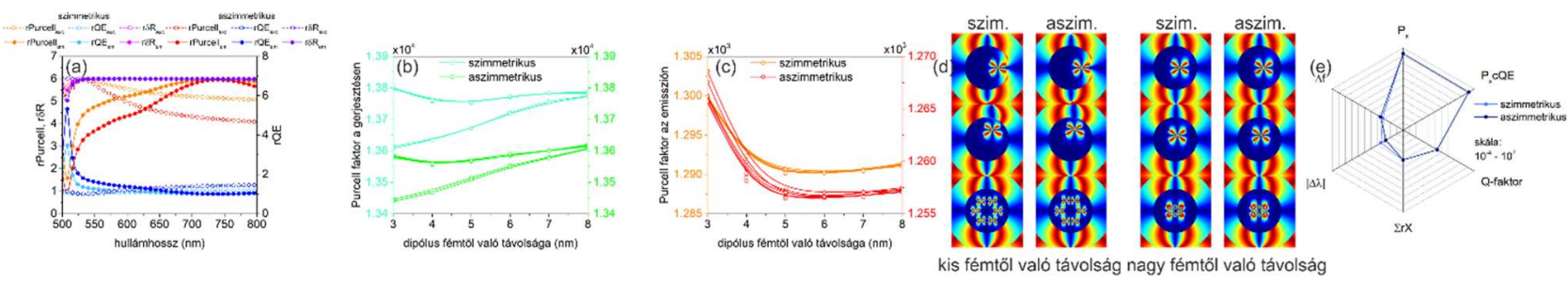

4. ábra

A legjobb szuperradiancia karakterisztikát mutató 6 SiV színcentrumot szimmetrikus és nem-szimmetrikus elrendezésben tartalmazó csupasz nanorezonátorok (a) relatív optikai jel erősítés, (b) Purcell faktor távolságfüggése a gerjesztésen és (c) emisszión, (d) átpolarizálás jelenségének távolságfüggése, (e) a szuperradiancia jósága.

Az analóg szimmetrikus mintázatokat tartalmazó szférikus nanorezonátorokhoz képest megfogalmazva az állításokat az aszimmetrikus mintázatokat tartalmazó nanorezonátorokra: a gyémánt-fém mag-héj nanorezonátorokban kisebb $\mathrm{P}_{\mathrm{x}}$ és $\mathrm{P}_{\mathrm{x}}{ }^{*} \mathrm{cQE}$, míg a jobban definiált bad-cavity karakterisztikával hatékonyabb szuperradiancia érhető el, de nagyobb elhangolással. Ezzel ellentétben a gyémánttal bevont mag-héj nanorezonátorokban minden reláció megfordult, kivéve a szuperradiancia hatékonyságát, ami nem mutat mintázat szimmetriától függést.

A nem-szimmetrikus mintázatok a csupasz ellipszoidális rezonátorokban kisebb (ugyanakkora) $\mathrm{P}_{\mathrm{x}}$ és $\mathrm{P}_{\mathrm{x}}{ }^{*} \mathrm{cQE}$ értéket, jobban definiált bad-cavity karakterisztikát, jobb szuperradiancia hatékonyságot, és kisebb elhangolást eredményeznek négy (hat) színcentrum esetében. A négy (hat) emitter nemszimmetrikus mintázatát tartalmazó gyémánttal bevont ellipszoidális nanorezonátorokban ugyanakkora (nagyobb) $\mathrm{P}_{\mathrm{x}}$ és $\mathrm{P}_{\mathrm{x}}{ }^{*} \mathrm{cQE}$ érték kisebb elhangolással és hatékonyabb szuperradiancia megvalósítással érhető el a kisebb (nagyobb) Q faktorral összhangban (ellentmondásban) (4. ábra).

\section{Komplex plazmonikus struktúrák emitterek erősítésére}

A kolloidgömb monorétegek interferáló nyalábokkal történő kivilágításával megvalósítható integrált litográfiával létrehozható komplementer konkáv és konvex nano-objektumokból felépülő struktúrák spektrális és közeltérbeli hatásait vizsgáltuk. Olyan komplex struktúrákat tanulmányoztunk, amelyek a $100 \mathrm{~nm}$ átmérőjü arany kolloidgömbök $60^{\circ}$ azimutális orientációban elhelyezett monorétegének 400 nm-es cirkulárisan polarizált fénnyel történő kivilágításával hozhatók létre, két $12.83^{\circ}$ szögben beeső interferáló nyalábbal (5. ábra) $[5,6]$.

(a)

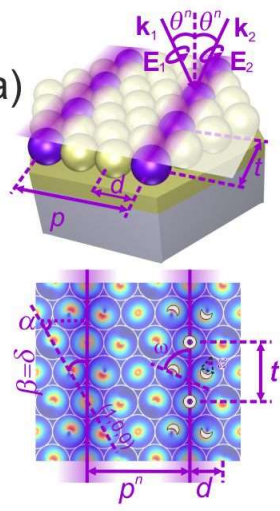

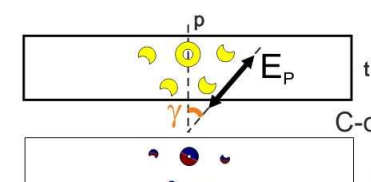

(b)

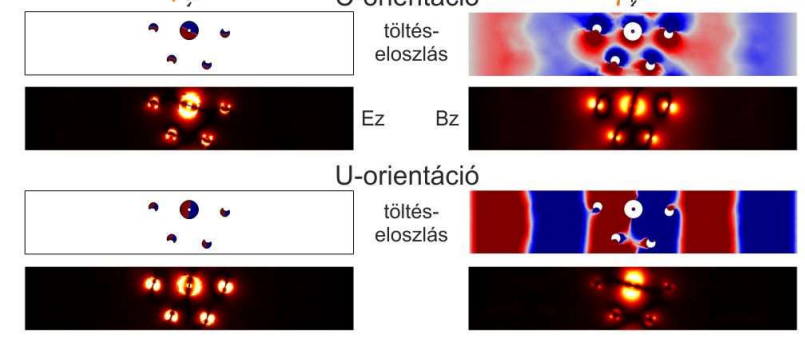

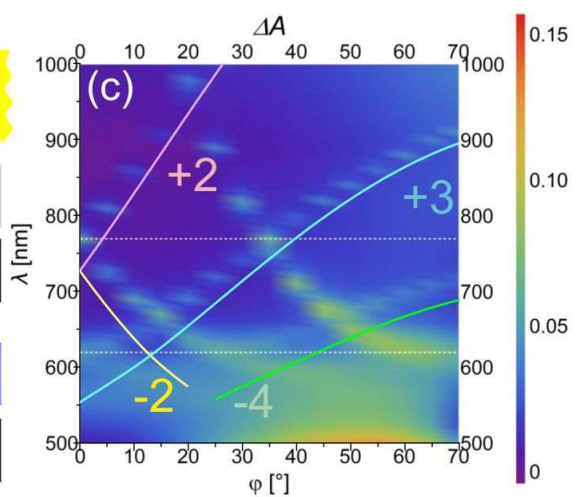

\section{5. ábra}

(a) Az integrált litográfia realizálása cirkulárisan polarizált fénnyel és a létrehozható mintázatok karakterisztikus geometriai paraméterei, (b) a komplex struktúrák egységcellája, töltés és közeltér eloszlás a globális maximumoknál a C (felől) és U (alól) rezonanciát eredményező azimutális orientációban a (balról) konvex és (jobbról) konkáv p=900 nm periódusú mintázaton,

(c) a p=900 nm periódusú konkáv mintázat diszperziós karakterisztikája. 
A spektrumszerkesztésre alkalmas lehetőségek demonstrálása céljából az analóg minimintázatokból felépülő konvex és konkáv $p=900 \mathrm{~nm}$ periódusú rektanguláris struktúrákat p-polarizált fénnyel világítottuk ki komplementer azimutális orientációkban. A $0^{\circ}$ és $90^{\circ}$ azimutális orientációkat vizsgáltuk az elfogatott nanoholdakon ún. „U” és „C” típusú lokalizált felületi plazmon rezonanciát (Localized Surface Plasmon Rresonance: LSPR) hatékonyabban eredményező $16^{\circ}$ és $106^{\circ}$ helyett, mivel a rektanguláris mintázatokon ezekben az irányokban leghatékonyabb a rács-csatolás. A vizsgált spektrális tartományban a $p=900 \mathrm{~nm}$ struktúra periódus okozhat csatolást, míg a $t=173 \mathrm{~nm}$ vertikális periódus nem eredményez modulációt. A $\mathbf{k}_{\mathrm{p}}$ vektorral párhuzamosan kisugározott fotonikus módus a $0^{\circ}$ azimutális orientációban a konvex mintázaton eredményezhet rács-csatolást (Surface Lattice Resonance), míg a konkáv mintázatokon a terjedő SPP módus a $\mathbf{k}_{\mathrm{p}}$ rács-vektorral $90^{\circ}$ azimutális orientáció esetében csatolható (5. ábra).
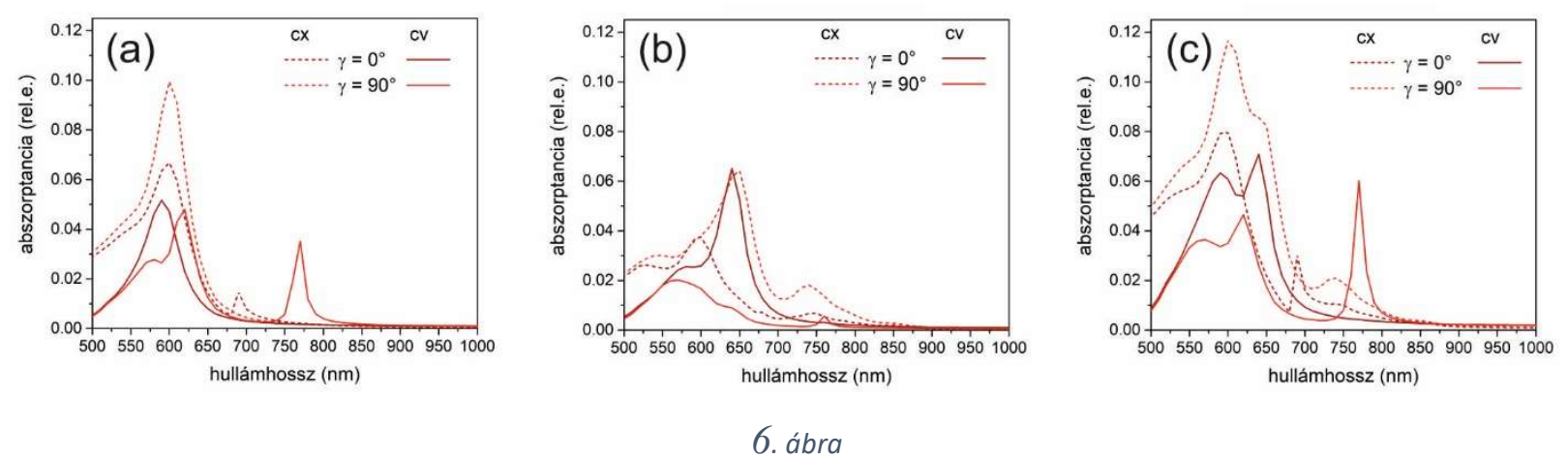

Centrális nanogyürűből, (b) nanoholdakból és (c) az ezekből képezett minimintázatokból felépülő p"=900 nm periódusú rektanguláris struktúrák abszorptanciája a komplementer azimutális orientációkban.

A konvex és konkáv centrális nanogyürüből képezett rektanguláris struktúrán a periódustól függetlenül egy maximum $(600 \mathrm{~nm}$ és $590 \mathrm{~nm})$ jelenik meg a $90^{\circ}$ és $0^{\circ}(\sim \mathrm{C})$ azimutális orientációban. A konvex mintázaton a $0^{\circ}(\sim \mathrm{U})$ azimutális orientációban az LSPR-hez $(600 \mathrm{~nm})$ közeli spektrális tartományban SLR eredetü maximum jelenik $(690 \mathrm{~nm})$ meg. A konkáv gyürü-mintázaton a $90^{\circ}(\sim \mathrm{U})$ azimutális orientációban lokális-globális maximumpár jelenik meg $(580 \mathrm{~nm}, 620 \mathrm{~nm})$ a lokalizált rezonancia valamint a periodikus struktúrán terjedő SPP harmadrendben csatolása hatására. Mindemellett egy lokális maximum is megfigyelhető $(770 \mathrm{~nm})$, ami SPP másodrendủ rács-csatolására vezethető vissza. Ezen fotonikus (plazmonikus) csatolások azért hatékonyak, mert $0^{\circ}\left(90^{\circ}\right)$-ban oszcillál az E-mező a p periódushoz tartozó $\mathbf{k}_{\mathrm{p}}$ rácsvektorra merőlegesen (párhuzamosan) (6a. ábra).

A 6 konvex (konkáv) nanoholdból képezett mintázatot tartalmazó rektanguláris struktúrán a periódustól függetlenül két maximum között egy váll $(530 \mathrm{~nm}-590 \mathrm{~nm}-650 \mathrm{~nm})$ (egy váll és egy maximum $(580 \mathrm{~nm}-640 \mathrm{~nm})$ ) jelenik meg a $90^{\circ}\left(0^{\circ}\right)(\sim \mathrm{C})$ azimutális orientációban. A lokális - globális maximum az irodalom szerinti $\mathrm{C} 2$ és $\mathrm{C} 1$ rezonanciához tartozik, a $\mathrm{C} 2$ rezonancia a konkáv mintázat abszorpcióján a film abszorpciójának kivonása miatt nem azonosítható. Az $0^{\circ}\left(90^{\circ}\right)(\sim \mathrm{U})$ azimutális orientációban a részecske plazmon rezonancia $(530 \mathrm{~nm})$ után egy széles maximum jelenik meg (600 $\mathrm{nm}(570 \mathrm{~nm}))$, amely az irodalom szerinti U rezonanciához tartozik. Mindemellett kisebb moduláció $(675 \mathrm{~nm}(640 \mathrm{~nm}))$ is megfigyelhető a konvex (konkáv) mintázaton, azonban ennek szimmetria okból nem rács-csatolás az oka. A nanogyürütől eltérően a $0^{\circ}\left(90^{\circ}\right)(\sim U)$ azimutális orientációban a maximum modulációjához az vezet, hogy a vertikális (horizontális) irányban oszcilláló E-mező lehetővé teszi a $\mathrm{C} 1$ rezonancia kereszt-csatolását. A további lokális maximum $(750 \mathrm{~nm}(760 \mathrm{~nm}))$ közeltér csatolásra és a fotonikus (plazmonikus) módus gyenge másodrendben szórására vezethető vissza (6b.ábra). 
A minimintázatok spektrális válasza a centrális nanogyürü és szatellita nanoholdak válaszának összegétől csak kismértékben különbözik, ami arra utal, hogy a nano-objektumok között csak gyenge csatolás van. A holdak C2-C1 rezonanciája, valamint a gyürün és minimintázaton U orientációban bekövetkező LSPR és SPP harmadrendü csatolás hatására megjelenő modulációk nagyon hasonlóak (6c. ábra).

Minden struktúrára teljesül, hogy a konvex abszorptancia $0^{\circ} / 90^{\circ}$ azimutális orientációban megfeleltethető a konkáv abszorptanciának $90^{\circ} / 0^{\circ}$ azimutális orientációban, továbbá a töltés és közeltér eloszlások is komplementerek. Az eredmények igazolják, hogy az integrált litográfiával létrehozható mintázatokkal plazmonikus spektrumszerkesztés valósítható meg. EOT jelenség érhető el kontrollálható polarizáció érzékenységgel specifikus spektrális tartományokban. További vizsgálatok vannak folyamatban a geometria paraméterek variálásával determinálható meta-anyag karakterisztika feltérképezése céljából.

\section{5. Összefoglalás}

A kétdimenziós plazmonikus rácsok egyfoton detektorokba integrálásával megvalósítható az abszorpció maximalizálása és a polarizáció kontraszt is kontrollálható szimultán. Az egyfoton források plazmonikus nanorezonátorokban erősítésekor a nem-kooperatív fluoreszcencia növekedés / szupersugárzás optimalizálásához előnyösebb a nagyobb számú emitter, bevont/csupasz szférikus és csupasz/bevont ellipszoidális kompozíció, és az ellipszoidális geometria. A komplex struktúrákon is teljesül, hogy a konvex abszorptancia (reflectancia/transmittancia) komplementer azimutális orientációban megfelel a konkáv abszorptancia (transmittancia/refelektancia) jelnek, ami bizonyítja, hogy a komplementer mintázatokat komplementer nyalábokkal kivilágítva az optikai válaszok felcserélődnek a Babinet elvnek megfelelően. Mindemellett a töltés és közeltér eloszlása is analóg a komplementer orientációkban, ami lehetővé teszi fluoreszcens emitterek kontrollált erősítését.

\section{Köszönetnyilvánítás}

A projekt a Nemzeti Kutatási, Fejlesztési és Innovációs Hivatal támogatásával, az NKFI Alapból, „Optimalizált nanoplazmonika” (K116362) és az Európai Unió támogatásával, az Európai Szociális Alap társfinanszírozásával „Ultragyors fizikai folyamatok atomokban, molekulákban, nanoszerkezetekben és biológiai rendszerekben” EFOP-3.6.2-16-2017-00005 valósul meg.

\section{Irodalom}

[1] M. Csete, A. Szenes, D. Maráczi, B. Bánhelyi, T. Csendes, and G. Szabó, IEEE Photonics J. 9, 2, 1-11 (2017)

https://doi.org/10.1109/JPHOT.2017.2690141

[2] B. Tóth, A. Szenes, D. Maráczi, B. Bánhelyi, T. Csendes, and M. Csete, IEEE J. Sel. Top. Quant. 26, 3, 3900309 (2020)

https://doi.org/10.1109/JSTQE.2020.2987131

[3] A. Szenes, B. Bánhelyi, L. Zs. Szabó, G. Szabó, T. Csendes, and M. Csete, NPG Sci. Rep. 7, 13845 (2017)

https://doi.org/10.1038/s41598-017-14227-w

[4] D. Vass, A. Szenes, B. Bánhelyi, T. Csendes, G. Szabó, M. and Csete, Opt. Express, 27, 22, 31176-31192 (2019)

https://doi.org/10.1364/OE.27.031176 
[5] Á. Sipos, E. Tóth, O. Fekete, and M. Csete, Plasmonics, (2020) https://rdcu.be/caSJJ, https://doi.org/10.1007/s11468-020-01235-2

[6] E. Tóth, Á. Sipos, O. Fekete, and M. Csete, Plasmonics, (2020) https://rdcu.be/caL6q, https://doi.org/10.1007/s11468-020-01298-1 